\title{
Humanitarian Logistics Performance in the Light of Gender
}

\author{
Gyöngyi Kovács* \\ Supply Chain Management and Corporate Geography, HANKEN, Helsinki, Finland \\ Peter Tatham** \\ Centre for Human Systems, Cranfield University, UK
}

*) Corresponding author: Supply Chain Management and Corporate Geography, Department of Marketing, Hanken, Helsinki, Finland Tel. +358403521241, Fax +358933287, kovacs@hanken.fi

**) Department of Defence Management and Security Analysis, Cranfield University, UK Tel. +441793785734, Fax +441793785029, p.h.tatham@cranfield.ac.uk

Gyöngyi Kovács is Assistant Professor in Supply Chain Management and Corporate Geography at the Swedish School of Economics and Business Administration (Hanken) in Helsinki, Finland, where she also earned her PhD. She is the co-ordinator of the HUMLOG Group, a research network in humanitarian logistics. Her other research interests include sustainable supply chain management, supply chain collaboration, the abductive research approach, reverse logistics. Amongst others, her publications have appeared in the International Journal of Physical Distribution and Logistics Management and the Journal of Transport Geography. She is currently the European co-editor of the International Journal of Physical Distribution and Logistics Management. She can be contacted at kovacs@hanken.fi.

Peter Tatham joined the Royal Navy in 1970 and served in a variety of appointments during his career of some 35 years. Highlights include Logistics Officer of the Aircraft Carrier HMS INVINCIBLE in 1994/5 during Operations in Bosnia against the Former Republic of Yugoslavia and Chief Staff Officer responsible for all high level Personnel and Logistics issues emanating from the 10,000 sailors and 30 surface ships in the Royal Navy (1999-2000). His final three years in the Service were spent in the Defence Logistics Organisation where he was responsible for key elements of the internal programme of Change Management (20002004). During this period, he also gained an MSc in Defence Logistic Management. Following his retirement from the RN, he joined the staff of Cranfield University where he lectures on Defence and Humanitarian Logistics, and in Human Systems. He is also carrying out his doctoral research into the issues surrounding the role of shared values within military supply networks.

\begin{abstract}
Purpose - The aim of the article is to identify gaps in research and to set up a research agenda that investigates how gender attributes and different sets of skills contribute to logistics performance. The article focuses on humanitarian logistics and outlines the areas in which gender issues impact on the effectiveness of the provision of aid following a disaster.

Design/methodology/approach - A topical literature review on gender, humanitarian logistics, and logistics performance is used to unearth existing gaps in research.

Findings - Two main research gaps are of particular interest for humanitarian logistics in the light of gender: sex segregation in logistics, and the relation between gender and logistics skills; and the mitigation of gender disadvantages of beneficiaries. Here, a gendered access to aid can impact negatively on aid effectiveness.
\end{abstract}


What is original/value of paper - Literature is scant both on gender issues in logistics, as well as on humanitarian logistics. This article contributes to both areas, while evaluating the impact of gender on logistics performance.

Keywords Logistics skills, Logistics competence, Logistics performance, Not-for-profit sector, Gender attributes, Humanitarian logistics

\section{Paper Type Conceptual paper}

\section{Introduction}

Humanitarian logistics has received much media as well as research attention since the Indian Ocean tsunami in 2004. A key reason for this interest stems from the extent of logistics costs in a humanitarian operation, which has been estimated to lie in the region of $80-90 \%$ of the total expenditure of a humanitarian organisation (van Wassenhove, 2006). Another reason lies in disasters themselves, with their number, magnitude and effects showing an increasing trend (EM-DAT, 2008). This attention to the field has resulted in an increasing professionalisation of humanitarian logisticians, through an appreciation that training and education can provide tangible improvements to the effectiveness and efficiency of logistical support and, hence, to the recipients of humanitarian aid. Given that the ultimate aim of humanitarian logistics is to meet the requirements of "end beneficiaries" (Thomas and Mizushima, 2005), it is clear that the effectiveness of humanitarian logistics depends on how successfully the needs of different groups of aid recipients have been responded to.

The differences in needs between various groups of beneficiaries are significant. One dimension across which these needs differ relates to the gender of beneficiaries. Female and male beneficiaries can differ in their exposure to a disaster, their needs (and ability to articulate these), as well as their coping abilities and strategies (Enarson, 2002). Men leaving poverty-stricken regions to seek work elsewhere, or war-related violence targeting women are just two examples of gender disadvantages in the exposure to disasters (FAO, 2001). At the same time, the needs and coping strategies and capabilities of women and men differ due to their life situations, role in society and family, expectations and stereotypes (Delica, 2002). Many organisations have called for a "gendered" response in humanitarian aid (cf. ALNAP, 2005; Enarson, 2002), and even designed gender-differentiated action plans (e.g. FAO, 2001). But although several reports of humanitarian organisations have postulated the need for including gender considerations in disaster response, research to date has not investigated the role humanitarian logisticians can play in mitigating such gender disadvantages in disasters.

Humanitarian logisticians need to understand the differences in the circumstances of beneficiaries in order to improve their ability to meet their needs. Such an understanding starts with identifying different groups of beneficiaries, evaluating their needs, and then developing the appropriate response. Gender sensitivities are particularly highlighted at two interfaces between beneficiaries and humanitarian logisticians: the area of needs assessment, and the "last mile" problem of delivering the required items to beneficiaries. To this extent, the logistician's awareness of gender-related problems, and their ability to overcome the practical consequences, has a direct bearing on the effectiveness of an aid programme. Thus, the need to consider issues of gender applies not only in aid programmes but also within humanitarian supply chain. Indeed, Broadbridge and Hearn (2008) suggest that gender relations in supply chains offer an immense scope for further research.

More than just a question of gender, "good" logisticians have been stated to need a particular set of skills. A number of "skills for logistics" projects have investigated which set of skills is particularly valuable (Gammelgaard and Larson, 2001; Mangan and Christopher, 
2005; van Hoek et al., 2002) and the resultant requirement that these skills and competencies should be emphasised in logistics education (Hannon, 2004; Mangan et al., 2001). Going one step further, Wouters and Wilderom (2008) show that different sets of skills can be linked to the logistics performance of an organisation. Such differences in skills have, in turn, been attributed to the sex of the logistician, e.g. Min et al. (1995) highlighting the effects of gender in purchasing negotiations, and the latest Ohio State survey on women in logistics focusing on the particular leadership skills of female logisticians (CSCMP, 2006). In the humanitarian context it can, therefore, be seen that gender issues arise not only at the interface with the recipients of assistance, but also in respect of the gender of the logistician responsible for delivering the aid.

There are multiple ways through which "gender issues" can be linked to logistics skills, and in turn to logistics performance. Yet research on both the topic of logistics skills as well as that of gender and logistics has been scant. This article is designed, therefore, to explore the question of what makes a "good" humanitarian logistician. More specifically, the aim is to identify gaps in research and to set up a research agenda that will investigate how gender attributes and different sets of skills contribute to logistics performance. The article begins by defining the empirical problems of gender issues in humanitarian logistics, before positioning them in literature and thus, identifying the gaps in current academic research. Next, the relation between gender issues and logistics performance is discussed, before presenting a concluding research agenda and specific avenues for further research.

\section{The Empirical Problem}

There is ample anecdotal evidence of gender-related problems in humanitarian logistics. Such evidence can be found in many practitioner journals and newsletters of humanitarian organisations. Additional discussions with humanitarian logisticians were used to assemble their empirical problems related to gender issues. Defining the empirical problems first was deemed particularly important in order to ensure the validity of the subsequent research. As a result, the following initial problems were identified:

- Gender-specific needs. As outlined in the introduction above, men and women are exposed differently to disasters and have different capabilities for coping with these (Delica, 2002). Even the location of beneficiaries can differ across the sexes, e.g. women living in rural areas where men had left to work in poverty-stricken regions (Fordham, 2002). In a useful overarching phrase, Enarson (2002) coined the term of "women's disaster vulnerability" to cover this aspect of the problem. Differences in needs also arise from the sex of the beneficiary (e.g. in sanitation and health-related questions - see Burki, 2006), the traditional role of the sexes as well as the coping mechanisms they develop. The traditional role of men vs. women includes safety questions for men being more important during activities such as looking for firewood, while for women this is more important whilst accompanying children to school. As another example, Weekes-Vagliani (1994) describes the female tradition of buying and selling activities in Ghana as an important factor in determining whom to include when fostering entrepreneurship in the region.

- Gender-insensitive purchasing. There are also many examples of gender-insensitive purchasing decisions leading to safety and hygiene problems. One such was the use of translucent tents in El Salvador, which showed when women were alone and thus, exposed them to violence (ALNAP, 2005). Another is the anecdotal evidence suggesting that a particular humanitarian organisation purchased only one size of female underwear for beneficiaries in the Indian Ocean tsunami. 
- Last mile problems - gendered access to aid. Women and men experience differences in gaining access to aid. Firstly, women may have more difficulties in articulating their needs - either due to the fact that needs assessment teams have no access to them, or because of their traditional role in society. The first point can include a gendered lack in transport accessibility (Dayal, 2008; de Vos et al., 2008) as well as problems that arise from a lack of female logisticians in situations in which cultural factors inhibit men from investigating women's needs directly from them. Moreover, Enarson (2002) criticises the distribution of relief items via male-headed households, which puts e.g. widows and single women at the risk of not receiving aid. Even the timing of the distribution of relief items plays a role here, as "wrong" timing can inhibit particular beneficiaries from attending an event (cf. Lutz and Gady, 2004). Another example of last mile problems is the deliberate limitation of access. Here, anecdotal evidence quotes the example of only two sanitary pads being given out to female beneficiaries in a refugee camp at a time, an action that clearly did not take into account the needs pattern that is dictated by women's health.

In summary, not only the disaster and the existing societal structure, but also the decisions made by logisticians as to how to distribute aid can generate gender-specific problems in humanitarian aid. Here, both the skills and the sex of the logistician contribute to gendered disadvantages of beneficiaries.

\section{Gaps in Logistics Literature}

Having established some of the empirical problems that served as the initiators of our research, we conducted a topical literature review following the key areas of gender-specific needs, gender-insensitive purchasing and gendered access to aid. The literature search was completed using a number of different databases (Business Source Premier, Emerald, ABI/Inform, JSTOR etc.) through appropriate keyword searches, and the first hits led to a more comprehensive review of commonly cited articles. The narrow searches for literature on the previously outlined topics were followed by broader searches for keyword combinations such as

- "gender" and "logistics"

- "gender" and "supply chain"

- "gender” and "humanitarian”

and combinations of the above. Additionally, a review of practitioner literature was undertaken focusing, in particular, on working papers, internal brochures and newsletters of humanitarian organisations. Many of the articles found through the keyword search were general population surveys that used a logistical regression. These subsequently excluded from the analysis of the literature. Such articles discussed demographics related to e.g. academic careers (Ehrmann, 2007; Probert, 2005), social capital (Bassani, 2008) and organisational structures (Peterson and Philpot, 2006). While many of the topics were relevant to this research, we focused on the literature that explicitly linked gender- and skills-related matters to logistics.

Gender studies in logistics are relatively limited in terms of their breadth and depth, although there are some much-quoted publications that relate logistics to "gender issues". There is an abundance of surveys on the representation of women in logistics in different countries (typically done by and via the mailing lists of professional organisations, such as The Logistics Institute in Canada, CILT in the UK, or the "Ohio State" survey among female 
CSCMP members etc.), all suggesting a difference in male and female career patterns in logistics (Lynagh et al., 1999) as well as an under-representation of women in logistics - even though Trunick (2007) criticises such surveys for not capturing all women in the field. He mentions two causes for this problem: Firstly, many women working in logistics have no professional education and are therefore not members in any professional organisation and, as a result, are not captured via the surveys quoted above. Secondly, he points out that the definition of a "logistics job" remains unclear, and in many countries those engaged in purchasing and warehouse management or even forwarders belong to different professional organisations that are again not captured by such surveys. Furthermore, a much quoted reason for a lack of female logisticians is the male image of logistics - which relates to logistics language as much as to logistics being (perceived as) an engineering-related field (EP, 2007; Sohal and D'Netto, 2004), in which male representation typically dominates (Broadbridge and Hearn, 2008). In addition, there is anecdotal evidence that the antecedents of logistics (i.e. the areas of trucking and warehousing which were predominantly male occupations) still exist as a mental image of the current profession.

The latest Ohio State survey links gender issues to logistics leadership (CSCMP, 2006). Other studies also take a skills view on gender in logistics: Min et al. (1995) take up the question of negotiation skills based on the gender of purchasing professionals. According to their study, situations with mixed-gender negotiation partners can "soften" the negotiation, even though this only occurred in the moment of initial contact. Thus Min et al. (1995) treat gender as "noise" impacting on the negotiation skills of logisticians. Both skills and gender issues are therefore taken up in relation to logistics education (Chapman, 2007; Dinwoodie, 2001; Tracey and Smith-Doerflein, 2001).

From another angle, logistics has been blamed for increasing the need for work-related travels that affects men and women differently (Gustafson, 2006). By the same token, workrelated travel in global supply chains has also been shown to be an important barrier to women entering the logistics profession (Trunick, 2007). Granzin (1990) has further discussed consumer household logistics from a gender perspective, suggesting that the way of organising consumer logistics has an effect on who is participating in it, i.e. which members of the family collect items from retail stores and handle the goods.

When it comes to gender studies, Calás and Smircich (2006) list sex segregation of occupations, gender mainstreaming (acknowledging that global economic conditions do not affect wo/men equally), work/family conflicts as the three most important topics. Even though all three topics can indeed be found in logistics literature, to date the focus has mostly been on the issue of sex segregation of occupations, in particular on the lack of female logisticians. At the same time, work/family conflicts can also be related back to the question of sex segregation, as they are often quoted as the reason for women not entering the field of logistics (see Trunick, 2007). As a result of this analysis of the literature, we will now discuss the gender-related problems in humanitarian logistics from two key perspectives - those of sex segregation and of gender mainstreaming.

\section{Sex segregation in logistics}

Sex segregation in humanitarian logistics is highlighted in three ways: (a) as a lack of female logisticians in general, (b) in differences between male and female decision making in logistics, and (c) in differences in access to female beneficiaries caused by a lack of female humanitarian logisticians. As the sex of the logistician seemingly has an effect on how effectively the needs of beneficiaries are being met, the topic of sex segregation gains greater importance in humanitarian logistics. Development studies have for a long time been emphasising the importance of the representation of males and females in different 
institutions, and on different levels of the workforce (Weekes-Vagliani, 1994). But whilst it is easy to show representational figures for female vs. male logisticians in different countries and industries, it is the comparison across industries, and the comparison with fe/male ratios in other jobs in the same organisations that indicate fe/male representation. Different control factors to include in equal opportunities studies are previous job experience, age and organisational factors (Peterson and Philpot, 2006; Wouters and Wilderom, 2008). For example, Woodward and Winter (2006) have studied the under-representation of females in the British army; where a low percentage of female logisticians is hardly surprising, given that females are under-represented in the entire organisation. Taking this angle highlights the problem in humanitarian organisations the more. Aid organisations combining elements of social work and health care typically have a largely female workforce; yet even in organisations with over $90 \%$ females, the logisticians are typically male (e.g. Médecins Sans Frontières). Thus it would be important to understand what attracts or hinders women from entering the logistics profession, particularly when they are present in many other areas of such humanitarian organisations.

In considering this question, there is a lack of literature on how such an underrepresentation of females in logistics affects logistics decision-making and thus, the effectiveness of reaching (fe/male) beneficiaries. But even though there is an abundance of literature on personal and inter-personal skills related to gender (with links to be found in logistics literature; CSCMP, 2006; Trunick, 2007), the set of skills that are needed in humanitarian logistics have not been established. Rather, the logistics skills literature has focused on the "for profit" sector and in particular, on the differentiation between core logistical skills and general managerial skills that contribute to being a good logistician, propagating a "T-shaped model” of logistics skills (see Mangan and Christopher, 2005). However, this model has not yet been tested in humanitarian logistics - and, indeed, not in business logistics, either!

Returning to the aim of humanitarian logistics, its focus on meeting the needs of beneficiaries needs to be emphasised. Aid effectiveness is crucially dependent on the way these needs are met; thus the effectiveness of humanitarian logistics contributes significantly to the effectiveness of the overall disaster relief response. Having said this, it is far from clearly established how effectiveness is or should be measured in humanitarian logistics, and how "the humanitarian logistician" and her/his skills contribute to the performance of an organisation. This is particularly surprising as, on the one hand, performance measurement is already established as a key research area in humanitarian logistics as evidenced by a rising number of publications on this topic (Beamon, 2004; de Brito et al., 2007). But on the other hand, as Wouters and Wilderom (2008) demonstrate, the performance indicators an organisation has selected drive the behaviour of logisticians and also impact on their job description.

\section{Gender mainstreaming in humanitarian logistics}

Whilst reports of humanitarian organisations do describe events in which men are more exposed to disasters than women (Bradshaw, 2001; Fordham, 2002), the focus of literature on gender disadvantages of beneficiaries is on women. In part, this focus reflects the lack of knowledge of women's capacities to cope with disasters (Delica, 2002). Enarson (2002) helpfully crystallises this debater through a difference between men's and women's "disaster vulnerability”.

The topic of "gender mainstreaming" is a recent trend in gender studies (Broadbridge and Hearn, 2008; Calás and Smircich, 2006). Thus, in humanitarian logistics, the focus is not only on gendered disadvantage(s) of aid recipients and of gender justice, but also on setting a 
political agenda to promote gender equality (FAO, 2001; Fonjong, 2001; IOM, 1998; SEAGA, 2002). In this sense, disasters can be seen (positively or negatively) as opportunities for development (Delica, 2002), though it remains questionable whose values are driving development and change (Hyder, 2007; Kandiyoti, 2007). In any case, access to different services, and aid in general, is often determined by the sex of the beneficiary. But whilst sex can be a determining factor of access to aid, how it determines this access depends on the cultural notion of male vs. female attributes, as well as regional traditions of division of labour (Delica, 2002). Weekes-Vagliani's (1994) example of the "female" tradition of buying and selling activities in Ghana emphasises the cultural specificity of gender socialisation - a theme that is also discussed by Broadbridge and Hearn (2008). In response, humanitarian organisations have begun to take a differentiated view on female beneficiaries, taking the cultural specificities of their socialisation into account (OCHA, 2006; Oxfam, 2005). At the same time, the societal implications of disasters, and disaster relief, have also been examined including through a gender lens (Rodrigues et al., 2005).

Access to assistance is thus, not just a matter of transport infrastructure and the availability of transportation services - though a demobilised transport infrastructure is of special interest to disaster relief (Kovács and Spens, 2007; Yi and Özdamar, 2007), and the availability and affordability of transportation services has also been linked to access to health care (de Vos et al., 2008), infant mortality and poverty (Dayal, 2008). Both in needs assessment and in educational programmes, even the timing of discussions can facilitate or inhibit different groups to attend an event (Lutz and Gady, 2004). A further aspect of access is the question of how the (limited) availability of relief items both in quantity as well as in variety affects the well-being of beneficiaries (cf. Marshall and Meiselman, 2006). Access is in this way seen as the next step to welfare, contributing to the empowerment of beneficiaries (Fonjong, 2001). In the context of humanitarian logistics, gender mainstreaming becomes a question of recognising and overcoming the gendered access to aid. Yet to date studies related to the accessibility of relief have not taken into consideration, how logistics, and logisticians, contribute to the setting of gendered conditions of access to relief.

Apart from the political agenda of gender mainstreaming, two further areas remain of particular interest to humanitarian logistics: the "gender-disaggregated needs" (ALNAP, 2005) related to health and sanitation-related questions (Fonjong, 2001; de Vos et al., 2008), and issues of personal safety (ALNAP, 2005; Kandiyoti, 2007). Much of this concerns the items that need to be purchased, and subsequently delivered to beneficiaries. Consequently, the SPHERE standards (quality standards and procedures for humanitarian organisations) have incorporated a gendered view (Sinha, 2005).

\section{Gender and Humanitarian Logistics Performance}

There is a vast body of literature on different attributes of logistics performance, though much of the focus is on particular metrics for each of these attributes, the definition of these metrics, and how to actually measure them. Generally, the focus of logistics performance is on effectiveness and efficiency. Breaking down these two, the debate centres on the measurement of product and process quality, on-time deliveries, flexibility, time and cost efficiencies, and customer service levels (Daugherty et al., 1994; Beamon 1999; Morgan, 2004). Here, time efficiencies relate to turnover measures (of e.g. inventory turnover) as well as financial measures (e.g. cash-to-cash cycle times) and on-time deliveries and lead times (cf. Beamon, 1999; Morgan, 2004). From a supply chain perspective, Stewart (1997) also includes the question of time to market from a product development perspective. Cost efficiencies are related to operational productivity (Caplice and Sheffi, 1994; Morgan, 2004), but also to capital reduction, and resource utilisation (again referring to inventory turnovers - Caplice and 
Sheffi, 1994). Customer service is another attribute that includes drivers from on-time deliveries to, interestingly, correct paperwork (Morgan, 2007). In essence, we need to relate the attributes of logistics performance to material flows as well as to information (cf. Moberg et al., 2004), and even financial flows (cf. Töyli et al., 2008). The latter is particularly important in the not-for-profit sector, given its need to ensure its financial stability (Beamon and Balcik, 2008).

Strikingly, much of the literature focuses on particular performance metrics - while logistics performance can be related to outcome as well as the process. A much-quoted process-oriented model is the supply chain operations reference model (SCOR) that originates from a benchmarking study (Stewart, 1997). The SCOR model identifies 19 strategic measures including asset turns, cash-to-cash cycle times, perfect order fulfilment, return on fixed assets etc., but can be criticised for the ambiguity of its measures which span managerial-operational or strategic levels (Morgan, 2007). Yet the most important attributes in the SCOR model can be summarised to be supply chain reliability, supply chain responsiveness, supply chain flexibility, and supply chain costs (Theeranuphattana and Tang, 2008). The differentiation between SCM- and logistics-related models is also evident in terms of external vs. internal measures of performance. Similarly, such a differentiation exists within logistics performance literature, where it has been discussed in terms of output-oriented and input-oriented measures. Thus, Beamon (1999) talks of input-related measures ('resources'), output-related measures, and the performance attribute of 'flexibility'. In essence, resources refer back to operational efficiency, whilst output refers to the effectiveness of an operation - or, in humanitarian logistics, the effectiveness of a mission (Beamon and Balcik, 2008). Flexibility has different sub-sets, referring to volumes, delivery times, and the mix of items (Beamon and Balcik, 2008). Another view on 'external' metrics is to differentiate between organisational-internal and customer, and shareholder metrics (Caplice and Sheffi, 1995). In the humanitarian sector, this would include donor metrics which helps to explain why additional attributes of logistics performance here include transparency and accountability of operations (de Brito et al., 2007; Beamon and Balcik, 2008).

Yet aid effectiveness depends on more than just donor metrics and the accountability of operations. Coming back again to the aim of humanitarian logistics which is to meet the requirements of beneficiaries, questions of gender influence the performance of a mission if the needs of a particular group of beneficiaries aren't met appropriately. Thus, to improve logistics performance, humanitarian logistics needs to overcome the barriers of any gendered access to aid. The definition of a mission or an aid programme can substantially contribute to the establishment of such barriers, or on the other hand to follow a design that particularly targets disadvantaged groups of beneficiaries. However, greater understanding - and more research - is needed into what constitutes gendered access to aid.

\section{Conclusions and Further Research}

The literature review has revealed a number of significant gaps in each of the streams of gender studies related to logistics. Studies on sex segregation in logistics have to date focused more on women's career patterns in logistics and less on what attracts and hinders women from entering the logistics profession. The area of humanitarian logistics is a particularly interesting context for such a study as here (predominantly male) logisticians work in an otherwise female-rich work environment. Yet, career-related questions not only dominate gender studies in logistics but are also generally the primary focus when it comes to the research of related research groups. Looking at the current research of other gender groups in logistics, our goal in setting a research agenda is guided by the principle of non-duplication of efforts and this topic is not, therefore, at the core of our intended research. 
Apart from a lack of studies on sex segregation in logistics, also, no study could be found that took a gendered view on the skills of logisticians. More importantly, no studies could be found that tested the existing skills models of a "good" logistician. We therefore propose to collect comparative data from business and humanitarian logisticians on the skills needed to become a "good" logistician. Such a study should take a gendered perspective on skills. Two ways can be envisaged for taking such a view: firstly, relating gender studies on each of the skills mentioned in logistics literature, and thus finding gender-specific indicators for each skill; or secondly, testing Mangan and Christopher's (2005) T-shaped model of logisticians, not only asking about the perceived relevance of each skill, but also attributing each skill to a male/female scale. A scale approach is proposed in order to take a differentiated view on gender, and avoid Broadbridge and Hearn's (2008) criticism of dualistic views that only contrast male/female attributes.

Following the second stream of literature in gender studies, it became apparent that gender mainstreaming is primarily a question of access in the context of humanitarian logistics. Here a "neighbourhood search" of current studies (looking at other current research projects that relate to the topic) revealed that gender mainstreaming research in humanitarian aid is primarily concerned with setting the political agenda of entire humanitarian programmes. Clearly such programmes do indeed set the constraints under which humanitarian logisticians operate; however there is at present no research conducted on how humanitarian logisticians set the conditions of access to relief for different groups of beneficiaries. This, therefore, represents an important avenue of research to be taken up in our future agenda. Moreover, while there is research on the cultural specificity of gender socialisation, there is no existing literature on how to respond to the resulting gender disadvantages from a logistics perspective.

The literature on gendered disadvantage also points at a gap in investigating the differences in needs of relief items across different gender groups. However, other studies are currently been undertaken on how to include such considerations in product standards also for relief items. This point is therefore not in focus on our research agenda.

In conclusion, two studies are proposed for our research agenda: Firstly, a study that investigates the links between gender, skills, and logistics performance. Literature does exist on each of the separate concepts but has not yet established the links between these. The study is envisaged as a survey among business and humanitarian logisticians, testing for differences between the two groups.

At the same time, a second study is proposed that evaluates how humanitarian logistics can mitigate gender disadvantages of beneficiaries. The focus of this study is to respond to the gendered access of beneficiaries to aid whilst taking into account the cultural specificities of such an access. Considering that this research area is much less established than the topic of logistics skills, qualitative methods are seen as more suitable for this study, collecting data from interviews and observations in the field, i.e. looking at the interfaces between beneficiaries and humanitarian logisticians.

Apart from these two studies, further research is needed into the impact of gendered disadvantages of beneficiaries, and gendered access to aid, on logistics performance. There is still a poor understanding of how the design of missions and aid programmes impacts on the possibilities of beneficiaries to access aid - and ultimately, on the aid effectiveness of a disaster relief mission. What is more, no studies could be found to date that would look at the interdependence of material, information, and in particular, financial flows in humanitarian logistics. Further research is undoubtedly needed to increase the understanding of the impact of funding schemes on humanitarian logistics. 


\section{References}

ALNAP (2005), "South Asia Earthquake 2005: Learning from previous earthquake relief operations", At: www.odi.org.uk/ALNAP/publications/pdfs/ALNAPProVention_SAsia_Quake_Lessonsa.pdf accessed 10 Jul 07

Bassani, C. (2008), “The influence of financial, human and social capital on Japanese men's and women's health in single- and two-parent family structures”, Social Indicators Research, Vol. 85 No.2, pp.191-209.

Beamon, B.M. (1999), "Measuring supply chain performance”, International Journal of Operations and Production Management, Vol.19 No.3, pp.275-292.

Beamon, B.M. (2004), "Humanitarian relief chains: issues and challenges", Proceedings of the $34^{\text {th }}$ International Conference on Computers and Industrial Engineering, San Francisco, CA, USA.

Beamon, B.M. and Balcik, B. (2008), "Performance measurement in humanitarian relief chains”, International Journal of Public Sector Management, Vol.21 No.1, pp.4-25.

Bradshaw, S. (2001), "Reconstructing roles and relations: women's participation in reconstruction in post-Mitch Nicaragua", Gender and Development, Vol.9 No.3, pp.7987.

Broadbridge, A. and Hearn, J. (2008), "Gender and management: new directions in research and continuing patterns in practice”, British Journal of Management, Vol.19 (2008), pp.S38-S49.

Burki, E. (2006), “The Pakistan Earthquake and the health needs of women”, Humanitarian Exchange, No.34, pp.12-13.

Calás, M.B. and Smircich, L. (2006), "From the 'woman's point of view' ten years later: towards a feminist organization studies", in Clegg, S.R.; Hardy, C. and Nord, W.R. (eds.), Handbook of Organization Studies, London: Sage, pp.218-257.

Chapman, T. (2007), “Career solutions: Meet the Teachers”, Inbound Logistics, Jun 07.

CSCMP (2006): 2006 Career patterns of women in logistics. At: http://cscmp.org/Downloads/Public/Career/06CareerPatternsWomen.pdf, accessed 27 Jul 07.

Daugherty, P.J., Ellinger, A.E. \& Gustin, C.M. (1996), "Integrated logistics: achieving logistics performance improvements”, Supply Chain Management: an International Journal, Vol.1 No.3, pp.25-33.

Dayal, R. (2008), “Opinion: ‘Transporting’ people out of poverty”, Businessline, Jan 8, 2008, p.1.

de Brito, M., van der Laan, E. and Vergunst, D. (2007), "Humanitarian organisations and performance measurement", In: Tatham, P. (ed.): CD-ROM Proceedings of the International Humanitarian Logistics Symposium, Faringdon, UK

de Vos, P., Vanlerberghe, V.; Rodríguez, A., García, R., Bonet, M. and van der Stuyft, P. (2008), "Uses of first line emergency services in Cuba”, Health Policy, Vol.85 No.1, pp.94-104

Delica, Z.G. (2002), “Chapter 1: Enhancing women's capacity to manage and recover from disasters”, In: ILO InFocus Programme on Crisis Response and Reconstruction, Crises, women and other gender concerns, Working Paper 7. At: www.ilo.org/public/english/employment/crisis/download/wp7.pdf accessed 10 Jul 07, pp.1-3.

Dinwoodie, J. (2001), “Motivational profiling of logistics Master's students in Great Britain”, International Journal of Physical Distribution and Logistics Management, Vol.31 No.3, pp.187-202. 
Ehrmann, N. (2007), "From the ghetto to the ivory tower: Gendered effects of segregation on elite-college completion”, Social Science Quarterly, Vol. 88 No.5, pp.1392-1414.

Enarson, E. (2002), “Chapter 2: Gender issues in natural disasters: talking points on research needs”, In: ILO InFocus Programme on Crisis Response and Reconstruction, Crises, women and other gender concerns, Working Paper 7. At: www.ilo.org/public/english/employment/crisis/download/wp7.pdf accessed 10 Jul 07, pp.5-12.

EM-DAT (2008), EM-DAT -Emergency Events Database, Centre for Research on the Epidemiology of Disasters (CRED), Université Catholique de Louvain, Belgium, available from http://www.emdat.be/, accessed Mar 15, 2008.

EP (European Parliament) (2007), “Women and Transport (Provisional Version)”, IP/B/TRAN/ST/2005-008 dated 26 Jun 06.

FAO (Food \& Agriculture Organisation) (2001), Gender and Development Plan of Action 2002-2007, At: www.fao.org/sd/2002/PE0103_en.htm, accessed 15 Jul 07.

Fonjong, L. (2001), "Fostering women's participation in development through nongovernmental efforts in Cameroon”, The Geographical Journal, Vol.167 No.3, pp.223234.

Fordham, M (2002), “The place of gender in earthquake vulnerability and mitigation”. At: www.iiasa.ac.at/Research/RMS/july2000/Papers/fordham0208.pdf accessed 9 Jul 07.

Gammelgaard, B. and Larson P. (2001), "Logistics skills and competencies for supply chain management”, Journal of Business Logistics, Vol.22 No.2, pp.27-50.

Granzin, K. (1990), "The consumer logistics system: a focal point for study of the householdconsumption process”, Journal of Consumer Studies and Home Economics, Vol.14 No.3, pp.239-256.

Gustafson, P. (2006), “Work-related travel, gender and family obligations”, Employment and Society, Vol.20 No.3, pp.513-530.

Hannon, D. (2004), “Academic programs prepare the logisticians of tomorrow”, At: www.purchasing.com/article/CA416135.html accessed 23 Jul 07.

Hyder, M. (2007), "Humanitarianism and the Muslim world", Journal of Humanitarian Assistance, At: www.jha.ac accessed 5 Nov 07.

IOM (International Organization for Migration) (1998), “Gender mainstreaming in IOM”, At: www.iom.int/jahia/webdav/site/myjahiasite/shared/shared/mainsite/published_docs/broc hures_and_info_sheets/048_98\%20gender\%20mainstreaming\%20in\%20iom.pdf, accessed 15 Jul 07.

Kandiyoti, D. (2007), "Old dilemmas or new challenges? The politics of gender and reconstruction in Afghanistan”, Development and Change, Vol.38 No.2, pp.169-199.

Kovács, G. and Spens, K.M. (2007), "Humanitarian logistics in disaster relief operations”, International Journal of Physical Distribution and Logistics Management, Vol.37 No.2, pp.99-114.

Lutz, V.A. and Gady, C.E. (2004), "Necessary measures and logistics to maximize the safety of victims of domestic violence attending parent education programs”, Family Court Review, Vol.42 No.2, pp.363-374.

Lynagh, P. M., Murphy, P. R., and Poist, R. F. (1999), "Career perspectives of women in distribution: congruency or contrast”, International Journal of Physical Distribution and Logistics Management, Vol.29 No.9, pp.192-206.

Mangan, J. and Christopher, M. (2005), "Management development and the supply chain manager of the future", International Journal of Logistics Management, Vol.16 No.2, pp.178-191. 
Mangan, J., Gregory, O., and Lalwani, C. (2001), "Education, training and the role of logistics managers in Ireland", International Journal of Logistics: Research \& Applications, Vol.4, No.3, pp.313-327.

Marshall, D.W. and Meiselman, H.L. (2006), "Limited choice: An exploratory study into issue items and soldier subjective well-being”, Journal of Macromarketing, Vol.26 No.1, pp.59-76.

Min, H.; LaTour, M.S. and Jones, M.A. (1995), "Negotiation outcomes: The impact of the initial offer, time, gender, and team size”, The Journal of Supply Chain Management, Vol.31 No.4, pp.19-24.

Moberg, C.R, Whipple, T.W, Cutler, B.D. and Speh, T.W. (2004), "Do the management components of supply chain management affect logistics performance?”, International Journal of Logistics Management, Vol.15 No.2, pp.15-30.

Morgan, C. (2004), "Structure, speed and salience: performance measurement in the supply chain”, Business Process Management Journal, Vol.10 No.5, pp.522-536.

Morgan, C. (2007), "Supply network performance measurement: future challenges?", International Journal of Logistics Management, Vol.18 No.2, pp.255-273.

Murphy, P. and Poist, R. (2007), "Skill requirements of senior-level logisticians: a longitudinal research assessment”, Supply Chain Management: An International Journal, Vol, 12, No. 6, pp. 423-431.

OCHA (Office for the UN Coordination of Humanitarian Affairs) (2006), “Ten Lessons for OCHA - The Tsunami Evaluation Coalition, the South East Asia Earthquake and the Lebanon Crisis)", At: http://ochaonline3.un.org/ocha2006ar/html/part1_tenkeylessons.html accessed 27 Jul 07.

Oxfam (2005), “The tsunami's impact on women”, At: www.oxfam.org.nz/resources/The_tsunami_impact_on_women.pdf accessed 18 Jul 07

Peterson, C. and Philpot, J. (2006), "Women's roles on U.S. Fortune 500 boards: Director expertise and committee memberships”, Journal of Business Ethics, Vol.72 No.2, pp.177-19.

SEAGA (Socio-Economic and Gender Analysis Programme) (2002), "Passport to Mainstreaming a Gender Perspective”, FAO (Food and Agriculture Organization of the United Nations) and WFP (World Food Programme). At: www.fao.org/sd/seaga/downloads/En/passporten.pdf Accessed 23 Jul 07

Sinha, D. (2005), “Gender in Sphere Standards”, At: www.southasiadisasters.net accessed 27 Jul 07.

Sohal, A. S., and D’Netto, B. (2004), "Incumbent perceptions of the logistics profession”, International Journal of Logistics Systems and Management, Vol.1 No.1, pp.5-25.

SPHERE (2004), "Humanitarian Charter and Minimum Standards in Disaster Response”, The Sphere Project. (Guidance Note 2 to Common Standard 8).

Stewart, G. (1997), "Supply-chain operations reference model (SCOR): The first crossindustry framework for integrated supply-chain management”, Logistics Information Management, Vol. 10 No.2, pp.62-67.

Theeranuphattana, A. and Tang, J.C.S. (2008), “A conceptual model of performance measurement for supply chains: alternative considerations”, Journal of Manufacturing Technology Management, Vol.19 No.1, pp.125-148.

Thomas, A. and Mizushima, M. (2005), "Logistics training: necessity or luxury?”, Forced Migration Review, No.22, pp.60-61. 
Töyli, J., Häkkinen, L., Ojala, L. and Naula, T. (2008), "Logistics and financial performance. An analysis of 424 Finnish small and medium-sized enterprises”, International Journal of Physical Distribution and Logistics Management, Vol.38 No.1, pp.57-80.

Tracey, M. and Smith-Doerflein, K. A. (2001), "Supply chain management: what training professionals need to know”, Industrial and Commercial Training, Vol.33 No.3, pp.99104.

Trunick, P.A. (2007), “Women in logistics”, Logistics Today, Vol.48 No.12, pp.24-25.

van Hoek, R., Chatham, R. and Wilding, R. (2002), "Managers in supply chain management, the critical dimension”, Supply Chain Management, Vol.7 No.3, pp.119-125.

van Wassenhove, L. N. (2006), "Humanitarian aid logistics: supply chain management in high gear”, Journal of the Operational Research Society, Vol.57 No.5, pp.475-589.

Weekes-Vagliani, W. (1994), "Participatory development and gender: articulating concepts and cases”, OECD Development Centre Working Paper No.95, Feb 1994.

Woodward, R. and Winter, P. (2006), "Gender and the limits to diversity in the contemporary British Army”, Gender, Work and Organization, Vol.13 No.1, pp.45-67.

Wouters, M. and Wilderom, C. (2008), "Developing performance-measurement systems as enabling formalization: A longitudinal field study of a logistics department”, Accounting, Organizations and Society, Vol.33 No.4/5, pp.488-516.

Yi, W. and Özdamar, L. (2007), "A dynamic logistics coordination model for evacuation and support in disaster response activities”, European Journal of Operational Research, No.179 (2007), pp.1177-1193. 